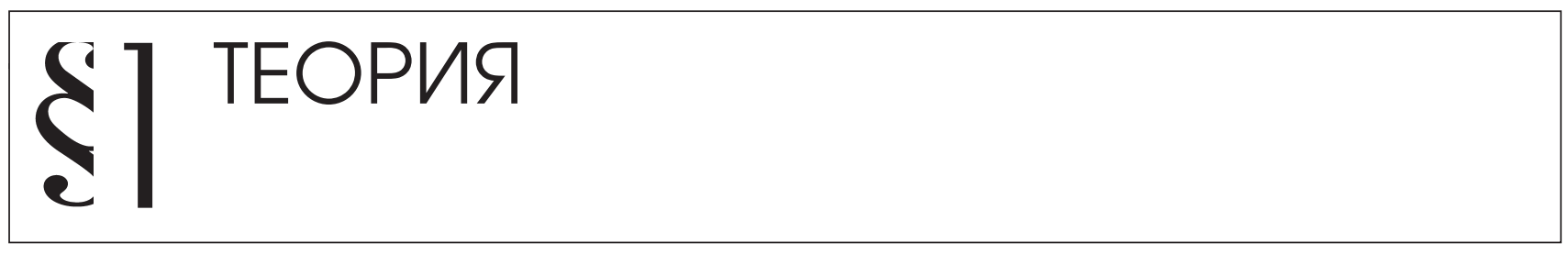

Кочетков В.В.

\title{
АНТИНОМИИ СОВРЕМЕННОГО РОССИЙСКОГО КОНСТИТУЦИОНАЛИЗМА: ФИЛОСОФСКО-ПРАВОВОЙ АНАЛИЗ
}

Аннотация: Автор данной работы считает, что существенной помехой на пути устойчивого демократического развития России являются определенные особенности российского конституционализма. Они заключаются в некоторых антиномиях, без разрешения которых невозможно создание ценностных предпосылок для реализации принцииов конституционализма в нашей стране. В статье показывается, что без понимания того, что свобода как частная и публичная автономия индивида может существовать только в пространстве вне дискрециии государственной власти, дух российской Конституичии будет оставаться невостребованным и нереализованным. В статье используется метод восхождения от абстрактного к конкретному в сочетании с авторским методом аксиологической экспликации феноменов правосознания. В статье впервые ставится вопрос о внутренней противоречивости современного российского конституционализма. Анализируются конкретные его антиномии и способы их преодоления. Основной вывод автора состоит в том, что необходима экспликация аксиологических оснований конституичионализма для имплементации духа Конституцчии 1993 года в систему госуправления.

Abstract: The author of this article considers that certain specific features of the Russian constitutionalism form significant obstacles in the way of sustainable democratic development in Russia. They are some antinomies, and it is not possible to form the value prerequisites for the implementation of the constitutionalism principles in Russia, unless these are resolved. It is proven in the article that without the understanding that freedom as private and public autonomy of an individual may only exist within the space outside the discretion of government power, the spirit of the Russian Constitution shall remain unclaimed and unimplemented. The article applies the method of ascent from the abstract to the specific with the author's method of axiological explication of the phenomena of the legal conscience. The article for the first time poses an issue of internal contradictions of the modern Russian constitutionalism. The main conclusion of the author is that there is need for an explication of axiological fundamentals of constitutionalism for the implementation of the spirit of the Constitution of 1993 into the state administration system.

Ключевые слова: конституцчионализм, власть, свобода, публичная автонимия, частная автономия, человеческое достоинство, Конституциия РФ, юридический разум, парадигма, правосознание.

Keywords: constitutionalism, power, freedom, public autonomy, private autonomy, human dignity, the Constitution of the Russian Federation, legal mind, paradigm, legal conscience.

итая труды современных российских юристов, посвященные конституционализму и теории конституции, невольно вспоминается известное замечание К.Маркса о том, что истина рождается как ересь, а умирает как догма. Конечно, как таковой, догматический метод - это основной юридический инструментарий и ставить его использование в упрек современным правоведам нельзя. Но все равно, остается ощущение, что некоторая непреходящая ценность конституционализма, его «ересь», совершенно не актуализируется при таком подходе. В общем и целом понятно, почему так происходит: конституционализм не является органичной для русской ментальности теоре- тической парадигмой, и его имплементация происходит по инициативе и под контролем властьпридержащих, а не гражданского общества. ${ }^{1}$ А российские юристы, как определенная профессиональная группа, всего лишь осуществляют рационализацию отношений господства (властеотношений) в нашем обществе, причем, как правило, с точки зрения веления оформленной в виде закона воли власти. Поэтому применение исклю-

\footnotetext{
${ }^{1}$ Принятие Конституции исторически всегда рассматривалось российской властвующей элитой как форма легитимизации своего господства, а не способ устроения общественной и политической жизни.
} 
чительно позитивистского юридического разума при заимствовании конституционализма серьезно, на наш взгляд, искажает аксиологическое содержание данной парадигмы. Это и приводит по меткому замечанию О.Е.Кутафина к ситуации, когда мы имеем в нашей стране «мнимый конституционализм» вместо свободы и демократии, на верность которым присягают российская власть и государствоведы. ${ }^{2}$

В данной работе мы пытаемся через анализ юридического понимания категории «свобода» выявить (1) особенности современного российского конституционализма, и (2) аксиологическое значение парадигмы конституционализма, которое должно лечь в основу новой российской юриспруденции и стать ориентиром для правоприменения.

На первый взгляд, как будто наши подозрения беспочвенны. Как пишет В.Д.Зорькин: «В определенном смысле Конституция есть выражение основных юридических ценностей, таких как права и свободы человека; верховенство права, справедливость и равенство; демократическое, федеративное, правовое и социальное государство; разделение властей; парламентаризм; правовая экономика». ${ }^{3}$ Эти ценности, по его мнению, образуют определенную иерархию, при которой высшей конституционной ценностью является норма о правах и свободах человека.

Что же такое права и свободы человека с точки зрения современного российского конституционализма? Прежде всего, это способ правового ограничения власти. Иначе говоря, ограничение государственного вторжения в сферу частной и публичной автономии личности осуществляется посредством признаваемых за каждым человеком неотъемлемых прав и свобод, которые не могут быть нарушены или произвольно ограничены. Б.С.Эбзеев по этому замечает: «Именно благодаря этим правам - экономическим, социальным и культурным, а также гражданским и политическим - государственная власть не только ограничивается по сферам своего проявления и способам воздействия, но и становится подзаконной. Наличие у индивида гарантированных прав и свобод превращает его в «равноправ-

\footnotetext{
${ }^{2}$ «Говоря о современном российском конституционализме, - пишет известный российский юрист, - нельзя не заметить, что он носит в значительной мере характер мнимого конституционализма, поскольку отличается неустойчивостью, возможностью обращения вспять, очевидной вероятностью перехода конституционных по происхождению и политической терминологии феноменов в свою противоположность - авторитаризм»// Кутафин О.Е. Российский конституционализм. М.: Норма, 2008. С.7.

${ }^{3}$ Комментарий к Конституции Российской федерации. Под ред. В.Д.Зорькина, Л.В.Лазарева. М.: Эксмо, 2009. С. 27-29.
}

ного партнера» государства, способного предъявлять к последнему правовые притязания, обоснованность которых устанавливает суд, и тем самым способствует утверждению законности в деятельности государства». ${ }^{4}$

Из такого понимания ясно видно, для чего нужны права человека как юридическая конструкция, как некое средство, но неочевидно, в чем их ценность, иначе говоря, остается неясным для чего человеку становиться равным государству. Может потому, что власть и государство являются некой фундаментальной угрозой желанию человека быть свободным? Да и вообще: насколько возможно равенство человека и государства?

С точки зрения современного российского конституционализма ответ на эти вопросы может быть таким: права человека эксплицируют идею права как такового и идею свободы как таковой. В.Д.Зорькин в этой связи отмечает: «Напомню, что слова «liberal», «свобода», «право» обозначают однопорядковые явления, поскольку право есть норма, мера свободы». ${ }^{5}$ Оставляя в стороне вопрос о том, может ли одно равнопорядковое явление быть мерой для другого однопорядкового с ним феномена, остается неясным, как такое понимание соотношения «свободы» и «права» может быть конкретизировано, особенно, если принять во внимание другой важнейший юридический постулат, который в изложении того же автора гласит: «Суть права - компромисс интересов на каждом данном этапе, [а] Конституция есть его высшее юридическое выражение». ${ }^{6}$

И здесь на выручку современному российскому конституционализму приходит догматический метод: «В государственной жизни, при осуществлении власти не должно быть ничего сверхправового, надправового. Именно на этой основе осуществляется соединение силы с правом (власть права и право власти). По своей сущности она является выражением права в его действии». ${ }^{7}$ Получается, что любая власть по своей природе легитимна, потому что она является правовой по своей сущности. Нужно только эту сущность обнаружить и прояснить, для чего, собственно, и требу-

\footnotetext{
${ }^{4}$ Комментарий к Конституции Российской федерации. Под ред. В.Д.Зорькина, Л.В.Лазарева. М.: Эксмо, 2009. С. 50.

${ }^{5}$ Комментарий к Конституции Российской федерации. Под ред. В.Д.Зорькина, Л.В.Лазарева. М.: Эксмо, 2009. С. 21. Для неюриста понятно, что мера как таковая предполагает измерение одного чем-то другим более высокого порядка абстракции, т.е. измерение возможно на основе определения через родовидовое отличие. Для некоторых юристов, как мы видим, это не очевидно.

${ }^{6}$ Комментарий к Конституции Российской федерации. Под ред. В.Д.Зорькина, Л.В.Лазарева. М.: Эксмо, 2009. С. 21.

${ }^{7}$ Комментарий к Конституции Российской федерации. Под ред. В.Д.Зорькина, Л.В.Лазарева. М.: Эксмо, 2009. С.22.
} 


\section{Право и политика 6 (174) • 2014}

ются юристы в государстве российском. А компромисс интересов в этой связи есть ничто иное, как общность интересов властвующей элиты, а не единство интересов граждан и государства, поскольку всем известно, что отдельные граждане не являются субъектами политики в нашей стране, хоть и обладают, согласно Конституции 1993 года, обширными правами человека и гражданина.

А что же такое право в этой связи? Для ведущих российских конституционалистов право по сути дела есть некое тождество определенных однопорядковых феноменов. В.Д.Зорькин дает следующее определение: «Право как норма свободы по своей природе есть справедливость, или юридическое равенство». ${ }^{8}$ Право, конечно же, не существует в природе как таковое. Оно находит свое выражение в законе, точнее говоря, оформляется в законе. Как замечает в этой связи В.С.Нерсесянц: «Ценность закона (позитивного права) и государства... состоит в их правовом значении и смысле. Цель права как должного в отношении закона (позитивного права) и государства можно сформулировать в виде следующего императива: закон (позитивное право) и государство должны быть правовыми». ${ }^{9}$ Но при этом, как отмечает В.Д. Зорькин, верховенство права не тождественно верховенству закона, т.к. при злоупотреблениях власти в форму закона может облекаться и произвол, хотя остается не ясным, как это вообще возможно при правовой то сущности власти. Границей же четко отделяющей закон как право от закона как злоупотребления власти является, согласно канонам конституционализма, мера соблюдения прав и свобод человека. Но и здесь, как мы увидим, необходимо соблюдать осторожность. Ведь право как норма свободы не означает, что свобода индивида абсолютна.

Основными границами прав и свобод человека, согласно ч. 3 ст.17 Конституции РФ, являются права и свободы других граждан. Точнее говоря, посредством норм права свобода индивида отграничивается от свободы других. Именно поэтому, наверное, в соответствии с ч.3 ст.55 Конституции РФ, права и свободы человека могут быть ограничены федеральным законом только в той мере, в какой это необходимо в целях защиты основ конституционного строя, нравственности, здоровья, прав и законных интересов других лиц, обеспечения обороны страны и безопасности государства. При этом, как считает В.Д.Зорькин, императив права о человеке как цели предполагает, что политическая целесообразность должна сообразовываться с правом, что, как мы помним, и является сущностью власти как таковой. Он даже пишет в этой связи: «Демократия и правовое государство должны защищаться от неправовых (антиправовых) и недемократических (антидемократических) действий исключительно правовыми и демократическими методами». ${ }^{10}$ Иначе говоря, право несовместимо с произволом, даже если он облечен в форму закона. Когда же периодически на наших глазах случается произвол по закону, то не надо верить глазам своим и искать глубокие причины. Ведь это всего лишь случайность, т.к. это суть неправовой закон, и он противоречит праву (свободе, справедливости, равенству), а значит и правовой сущности власти. В общем, как говорится, только суд может рассудить, что есть что, хотя, как всем известно, суд - это одна из трех ветвей власти, которая, в свою очередь, может не только применять право и закон, но и творить произвол.

И как же выйти из этих дебрей современного российского конституционализма? Эбзеев Б.С. поясняет: «Конституция не дает оснований обходить закон со ссылкой на право, поскольку это привело бы к размыванию конституционных функций и лишило бы Основной Закон рационализирующего и стабилизирующего действия, предусмотренного Конституцией». ${ }^{11}$ Этот вывод касается и всей системы федерального законодательства. И для чего тогда требуются нашему конституционализму такие рафинированные дифференциации права и закона, если даже правосудие, согласно ч.1 ст. 120 Конституции РФ, должно вершиться не на основе права (свободы, справедливости, равенства), а исходя из текстов Основного и других федеральных законов? А ведь самая главная опасность, на наш взгляд, состоит в другом. Если допустить такую возможность ссылаться на право при обсуждении российских законов, то власть российского государства может просто потерять свою легитимность даже под напором каких-нибудь «демагогов-правозащитников».

Зачем же тогда современный российский конституционализм взращивает идеологему «естественных прав человека» и даже закрепляет её в ст.2 Конституции? Скорей всего для того, чтобы доказать «правовую» сущность государства российского, ибо, как мы помним, любая власть как таковая является по при-

\footnotetext{
${ }^{8}$ Комментарий к Конституции Российской федерации. Под ред. В.Д.Зорькина, Л.В.Лазарева. М.: Эксмо, 2009. С. 28.

${ }^{9}$ Политико-правовые ценности: История и современность. Под ред. В.С. Нерсесянца. М.: Эдиториал УРСС, 2000. С. 11.
}

\footnotetext{
${ }^{10}$ Комментарий к Конституции Российской федерации. Под ред. В.Д.Зорькина, Л.В.Лазарева. М.: Эксмо, 2009. С.30

${ }^{11}$ Комментарий к Конституции Российской федерации. Под ред. В.Д.Зорькина, Л.В.Лазарева. М.: Эксмо, 2009. С. 53.
} 
роде своей правовой, и, следовательно, с принятием Конституции в 1993 г. в России появилось правовое государство. В.Д.Зорькин об исторических условиях принятия Основного Закона пишет следующее: «Народ, недовольный отсутствием какой-либо политической свободы и не имеющий опыта соединения права и свободы, первые же шаги на пути свободы принял как приглашение к вседозволенности. Всегда нечеткая в русской культуре грань между свободой и анархией... обнажила главный риск - риск потери государства и исторического бытия вместе с ним». ${ }^{2}$ Вот тебе и примат прав человека после советского государственного принуждения. Обоснование легитимности конкретного государственного устройства в новой России - вот чем на самом деле озабочены ведущие российские конституционалисты. А для неумеющих и непонимающих как надо соединять право и свободу есть старое проверенное средство - авторитаризм, который с точки зрения некоторых крупных российских конституционалистов не только допустим, но и даже закономерен. Как отмечает в этой связи В.Д.Зорькин: «Авторитаризм как элемент практики осуществления политической власти обусловливается особенностями переходного периода от неправового прошлого к новой демократии». ${ }^{13}$

Представляется, что теперь мы в состоянии сформулировать некоторые принципиальные особенности (ограниченности) российского конституционализма, которые находят свое выражение в антиномичности его трактовки категории «свобода».

Первую ограниченность можно определить как антиномию российской соииальности. С одной стороны, свобода человека вообще полагается высшей конституционной ценностью, которая должна определять правотворчество и правоприменение в нашем государстве. С другой же стороны, постулируется вековая неспособность реальных российских граждан разумно и ответственно пользоваться свободой, т.е. по сути дела, с точки зрения российских конституционалистов, они не могут вести правовую жизнь без попечения со стороны

\footnotetext{
${ }^{12}$ Комментарий к Конституции Российской федерации. Под ред. В.Д.Зорькина, Л.В.Лазарева. М.: Эксмо, 2009. С. 19. Любое проявление спонтанности гражданами российские государствоведы воспринимают как покушение на прочность государственной власти. Нам же представляется, что насилие, сопровождавшее принятие Конституции РФ в 1993г., свидетельствовало только о непринятии россиянами суперпрезидентских полномочий Б.Н.Ельцина, которые затем и были закреплены в Основном законе, а не о вековом неумении нашего народа соединять право и свободу. Именно исполнительная власть тогда попрала и право, и свободу!

${ }^{13}$ Комментарий к Конституции Российской федерации. Под ред. В.Д.Зорькина, Л.В.Лазарева. М.: Эксмо, 2009. С. 23.
}

властей. Получается, что в casus Rossica невозможна в принципе реализация свободы, а Конституция является декларацией о намерениях, а не документом прямого действия. Очевидно, что именно поэтому у нас принято так много законов, в которых под предлогом правового регулирования упрощаются и ограничиваются провозглашенные права и свободы. ${ }^{14}$

Вторая ограниченность проявляется в антиномии равенства человека и государства. Согласно догмам современного российского конституционализма, обеспечение примата свободы человека как высшей ценности возможно через правовое ограничение государственной власти. Тем самым власть наделяется независимым от граждан бытием. Она становится равным, а значит и равнозначным индивиду, а не производным от учредительной (договорной) свободы человека и гражданина, феноменом. Хотя, конечно же, в реальности это не возможно. Между прочим даже согласно теории права и практике государственного строительства, правоотношения равных сторон регулируются диспозитивным методом на основе свободного волеизъявления (договоpa), а отношения неравных субъектов - императивным методом. А ведь именно последний метод и является сущностью науки административного права, которая регулирует сферу публичной автономии человека и определяет механизм реализации прав и свобод граждан. Очевидно, что равенство человека и государства является фикцией и, по сути дела, она свободу индивида сводит к частной автономии, поскольку равнозначные субъекты, исходя из принципа равенства сторон, не могут вмешиваться в дела друг друга. Но если эту фикцию рассматривать во взаимосвязи с антиномией российской социальности, то и объем дискреции индивида в пределах частной сферы будет полностью зависеть от усмотрения властей.

Третья ограниченность современного российского конституционализма выражается в антиномии отождествления. Как мы поняли, для главных российских юристов право, свобода и т.п. являются явлениями одного порядка и содержание этих понятий, в сущности, совпадает. Представляется, что такое отождествление, присущее российскому конституционалистов, только усугубляет фикцию правового ограничения власти и позволяет редуцировать свободу к равенству, а справедливость - к праву, оформленному в законе. Такая

\footnotetext{
${ }^{14}$ Например, федеральные законы о митингах и собраниях, о референдуме, о политических партиях, об общественных организациях и многие другие существенно ограничивают конституционные права российских граждан, оставляя их практическую реализацию на усмотрение исполнительных органов власти.
} 


\section{Право и политика $6(174) \cdot 2014$}

нехитрая логическая конструкция позволяет подменить свободу, понимаемую в широком смысле как частную и публичную автономию социального субъекта, перечнем его некоторых прав и отдельных свобод, которые к тому же произвольно ограничиваются государством как правовым институтом по своей природе, возвышающимся над отождествленными феноменами. А если еще учесть и антиномию российской социальности, то получится, что любые равные ограничения свободы граждан со стороны государства будут правовыми.

Итак, очевидно, что принципиальные ограничения современного российского конституционализма не позволяют ему реализовать заявленный Конституцией РФ принцип приоритета прав и свобод человека в законотворчестве и правоприменении. Представляется, что для преодоления этой ситуации необходимо аксиологическое переосмысление парадигмы конституционализма.

В широком смысле под конституционализмом следует понимать философско-юридическую доктрину, а также реальную практику государственного строительства, которая считает возможным и необходимым строить на рациональной (договорной) основе систему государственного управления, взаимоотношений между гражданином и властью, а также между гражданами и даже между суверенными государствами. Эта доктрина исходит из признания равного достоинства за каждым свободно определяющимся (суверенным) субъектом социума (индивид или группа граждан) или международного сообщества (государство или народ). Данное признание достоинства реализуется через предикацию естественных и неотчуждаемых (гарантия свободы разума и воли в рамках правил поведения данного общества) прав (свободы делать / не делать что-либо) гражданина, объединений граждан, народов или государств, при условии признания последним (последними) и честного следования всей совокупности рациональных правил общественной, государственной и межгосударственной жизни. Иначе говоря, конституичионализм есть некая теоретическая парадигма, решающая задачу по разработке определенных принциипов справедливого устройства общественной жизни, которые бы позволяли обеспечить реализацию частной и публичной автономии для всех соичильных субъектов.

В этой связи также необходимо подчеркнуть, что конституция как политико-философский документ высшей юридической силы без конституционализма как определенной картины мира превращается, как правило, в фиговый листок правящего меньшинства, доминирующего над большинством. Властвующая элита через принятие конституции просто легитимирует свое господство перед мировым сообществом, подобно тому, как на заре становления европейских государств каждый племенной вождь мечтал получить королевскую корону из рук Папы римского. Да, появлялись короли, но народы солидаризировались, конституируясь в нации, не через регалии правящего меньшинства, а на основе чувства собственного достоинства. В современном мире наличие конституции также есть признак суверенности правительства и, следовательно, признания его другими правителями как легитимного и равного. Но наличие конституции, к сожалению, не свидетельствует о суверенности народа, о признании достоинства каждого человека через реальное гарантирование ему прав и свобод. Это также не свидетельствует о наличии в этой стране конституционализма как определенной картины мира.

В самом начале (в XVII - XVIII вв.) конституционализм являлся теоретическим решением проблемы «естественного состояния» человечества, которое прагматик Т.Гоббс описывал как состояние «войны всех против всех», а романтик Ж-Ж. Руссо - как идиллию первобытных дикарей, которых испортили хитрецы, придумавшие собственность, что в конечном итоге все равно вело к войне. Но для обоих вариантов естественного состояния было характерно отсутствие рационально организованной жизни, на основе принципов справедливости, и вследствие этого полное отсутствие свободы, так как не было даже гарантий личной безопасности. Такая ситуация с необходимостью ведет к тотальной борьбе за утверждение своего достоинства и за свою безопасность. А всякая борьба в социуме любого масштаба, как известно, приводит к иерархии и порождает власть. Необходимо подчеркнуть в этой связи, что понятие «власть» в конституционализме трактуется весьма широко: это и государственный аппарат, ${ }^{15}$ это и церковь, это и произвол судьи, это и власть над жизненными условиями человека через частную собственность, это и господство одной единственной идеологии. Очевидно, что рациональность и справедливость требуют признания равного достоинства за всеми социальными субъектами в иерархически организованном обществе, иначе невозможно избежать рецидивов «естественного состояния».

\footnotetext{
${ }^{15}$ Отождествление государства и его институтов/аппарата является важным теоретическим достижением конституционализма, так как позволяет избежать мистификации идеи «государства», лишает особого теоретического и политического статуса понятие «интересы государства» и т. п.
} 
А что же такое свобода и чем она ценна? Еще древние говорили, что omnis determinatio est negatio - всякое определение есть отрицание. Постановка проблематики свободы в философско-правовом дискурсе, по нашему мнению, должна звучать так: отрицанием чего является содержание понятия «свобода». Конституционализм как картина мира исходит из того, что пространство свободы возникает только вне сферы дискреции власти. Для этой доктрины контрадикторность оппозиции свободы и власти пронизывает всю систему и все уровни общественного разделения труда в любом типе социальности (семье, первичном трудовом коллективе, конфессиональном союзе, племени, современном государстве и т.д.). Именно поэтому власть необходимо ограничивать и разделять, так как этот общественный институт по своей внутренней логике тяготеет к всеобщности. Ибо по своей сути власть есть не что иное, как всего лишь монополизация некоторым социальным субъектом определенной общественной функции, а именно функции рационального целеполагания и контроля (т.е. управления), которые является основными характеристиками общественного бытия.

Всеобщность власти как акциденции (само)управления обществом может быть ограничена только институционально: или традицией, или правом. Последнее в конституционном смысле есть не что иное, как рационализация с помощью догматического метода властных отношений на основе норм морали, интерсубъективно принятых данным социальным субъектом (индивидом, родом, племенем, обществом, религиозным сообществом и т.д.). А моральная оценка, как известно, возможна только в отношении поступков свободной и ответственной (деликтоспособной, говоря юридическим языком) личности, обладающей объективным достоинством, то есть интерсубъективной значимостью в конкретном социуме. Без признания достоинства (или правосубъектности, согласно юридической терминологии) человека не возможна объективация его свободы. Ведь если кто-то недостоин признания быть человеком, то его удел, согласно известному определению раба, данному Аристотелем, быть мыслящим орудием в руках «настоящих» людей.

Именно поэтому конституционализм сопрягает категорию «свободы» и категорию «достоинство» человеческой личности в неразрывном аксиологическом синтезе. Человек эпохи Модерна, а тем более Постмодерна уже не мыслит себя состоявшейся личностью вне права, защищенного государством и признанным другими личностями - членами данного социума, на частную и публичную автономию. Как подчеркивал еще И.Кант: «Автономия есть основание достоинства человека и всякого разумного естества». ${ }^{16}$ Свобода индивида стала необходимым условием обретения им человеческого достоинства. Без признания этой взаимосвязи мы не можем говорить о человеке как о свободном и моральном существе, которое несет полную ответственность за свой выбор. Именно поэтому у юристов правосубъектность гражданина неразрывно связана с его деликтоспособностью.

Очевидно, что право на частную автономию как существенный аспект свободы человека в его государственном бытии предполагает наличие реальных возможностей для реализации личного жизненного проекта. А право на публичную автономию как другая сторона бытия свободы в государстве есть не что иное, как возможность реально влиять на содержание законов, а также на формы политики по их претворению в жизнь, так как именно от этого и зависит реализация своей концепции благой жизни.

Мировой опыт показывает, что наиболее целесообразное соединение в теории и на практике права на частную автономию с правом на публичную автономию достигается только в странах, где реализуется принципы конституционализма. Для того чтобы признание достоинства человеческой личности, ее права на частную и публичную автономию стали реальностью, а не оставались только теоретически выраженными ценностями, в рамках данной парадигмы были разработаны определенные принципы государственного строительства, направленные на ограничение сферы дискреции власти. Конечно, конституционализм как международное политико-правовое и культурное явление гораздо шире своей нормативной основы и конституционного права. Но у всех народов, избравших конституционализм в качестве доктрины государственного строительства, политические институты отвечают следующим требованиям:

- обеспечение государством реальных условий для частной и публичной автономии гражданина;

- верховенство права, имеющее своей целью защиту свободы и справедливости, а также основных прав человека и гражданина, особенно права собственности;

- ограничение сферы дискреции государственной власти институционально, а также независимым судом, применяющим право и законы, направленные на защиту свободы граждан;

\footnotetext{
${ }^{16}$ Кант И. Критика практического разума. // Кант И. Сочинения. В 6-ти тт. Т.4, ч.1. М.: Мысль, 1965. С. 278.
} 


\section{Право и политика $6(174) \cdot 2014$}

- формальное равенство всех (и рядовых граждан, и властьимущих) перед законом в своем праве на частную и публичную автономию;

- четкое разделение по вертикали и горизонтали государственной власти по полномочиям и способам легитимации;

- осуществление законодательной власти исключительно органом народного представительства;

- ответственность исполнительной власти перед высшим законодательным органом народного представительства.

Обобщая, можно сказать, что вышеперечисленные принципы составляют глубинную суть конституционализма, поскольку их реализация позволяет четко ограничить сферу дискреции власти, а значит и четко определить пространство свободы. Именно создание условий для частной и публичной автономии социального субъекта через ограничение сферы дискреции любой власти является целью конституционализма как определенной формы общественного сознания. Следовательно, говоря юридическим языком, такие ценности как «свобода» и «человеческое достоинство» должны определять дух любого текста конституции и законов, а самое главное - направлять практику правоприменения.

Однако все эти ценности и принципы госстроительства не могут быть реализованы без одного существенного культурного (неюридического) условия. Моральной предпосылкойлюбого конституционного (демократического) государства являются требования справедливости и честности. Иначе говоря, конституционализм невозможен без готовности всех граждан, и, прежде всего, элиты, к игре по определенным правилам, в том числе и к принятию собственного проигрыша. Именно поэтому необходимо, чтобы конституционализм стал своеобразной картиной мира для всех членов данного социума.

Необходимо также отметить, что сочетание теоретически выраженных ценностей свободы и достоинства с требованием честности и справедливости предотвращает превращение конституционализма в некий набор мертвых догм, поскольку требует давать на любые вызовы со стороны постоянно изменяющейся социальности только такие ответы, которые сохраняют, а лучше расширяют сферу частной и публичной автономии. Так, например, для доиндустриального капитализма была адекватна концепция «государства ночного сторожа», а на классовые противоречия индустриального капитализма был дан ответ в виде теории социального государства. ${ }^{17}$

\footnotetext{
${ }^{17}$ Более подробно этот вопрос был рассмотрен нами в: Кочетков В.В. Еще раз о сущности социального государства.// Закон и право, 2009 , № 7. С. 5-13. См. также: Кочетков В.В., Кочеткова Л.Н. Со-
}

В заключение рассмотрим как возможно преодолеть антиномии современного российского конституционализма на основе предложенной нами аксиологической интерпретации данной парадигмы.

Антиномия российской социальности снимается как иррелевантная проблеме построения свободного общества. Ссылки на вековую неспособность российских граждан к бытию в свободе означают не что иное, как приписывание им массовой юридической недееспобности и обосновывают по сути дела необходимость сильного государственного принуждения, не смотря на то, что существует конституционный приоритет прав и свобод граждан. А это, как мы показали, сужает пространство свободы как таковой за счет расширения дискреции государственной власти. С точки зрения конституционализма якобы массовая неспособность российских граждан к бытию в свободе в рамках российских законов свидетельствует об отсутствии свободы вообще и о несправедливости существующей системы власти, которая дискриминирует сферу частной и публичной автономии. Поскольку любая власть есть всего лишь монополизация функции управления, постольку «вина» наших сограждан лишь в том, что они не борются за ограничение этой монополии, а живут в плену иллюзии равноценности государственной власти и человека. ${ }^{18}$

Этой слепоте способствует и вторая ограниченность современного российского конституционализма, которую мы описали как антиномию равенства гражданина и государства. Суть этой антиномии с точки зрения аксиологического конституционализма заключается придании государственной власти независимого (равноценного) от граждан бытия через якобы правовое её ограничение. Равенство власти и гражданина как красивый правовой принцип на самом деле умаляет свободу такого социального субъекта как народ. Как известно, эта некая совокупность граждан, сплоченная на определенной территории интерсубъективно признаваемыми нормами свободы и справедливости, обладает своим достоинством, которое объективируется и теоретически осмысливается как суверенитет. Следовательно, государственная власть становится подзаконной (правовой) не потому, что она равна от-

циальное государство как идеальный тип.// Труд и социальные отношения, 2010, № 6. С. 106-115.

${ }^{18}$ Представляется, что в данном случае уместно говорить не о вине народе в целом, а о безответственности и своекорыстии российской элиты и интеллигенции, так как именно они в силу общественного разделения труда управляют и полагают цели, рационализируют и распространяют ценности. 
дельному гражданину, а потому что она производна от учредительной власти совокупности граждан, от суверенитета народа. ${ }^{19}$

Третья антиномия, суть которой состоит в отождествлении права, свободы и справедливости с равенством, является принципиальной догмой отечественного правоведения. Как известно, любое отождествление создает возможность подмены чего-то одного другим, которое, хотя и является элементом тождества, тем не менее, остается другим явлением со своей собственной природой. Именно это и происходит с современным российским конституционализмом, лишенным критериев разграничения права, свободы, справедливости и равенства. Он это отождествление доводит до абсурда, когда государство становится по своей природе правовым явлением, а равенство в ограничении свобод граждан - квинтэссенцией российского права. Тем самым любая критика существующей оформленной в закон воли власти становится заведомо несправедливой и неправовой. А самое главное - такое отождествление подрывает основу правосудия, т.е. соотнесение нормативного акта или деяния с нормами справедливости. В этом случае у закона есть презумпция выражения норм права на том основании, что в нем оформлено веление власти, прошедшее определенную процедуру издания, даже если оно попирает свободу. ${ }^{20}$

Завершая, хочется еще раз подчеркнуть следующее. Юридическая картина мира оказывает существенное влияние на жизнедеятельность людей тем, что определяет границы их свободы и тем, как разрешаются конфликты внутри гражданского общества, а также между гражданами и органами государственной власти. Она также легитимирует действия властвующей элиты, давая ей юридическое обоснование для преследуемых ей же целей. Поэтому только аксиологическая интерпретация конституционализма позволяет гражданам найти твердые основания для своего достоинства и для отстаивания своих прав, а для элиты дает новый морально-правовой критерий оценки своей деятельности. От того насколько такая картина мира будет им-

\footnotetext{
19 Теоретическое положение о договорном (учредительном) происхождении конституционного государства лишает самостоятельной ценности такое понятие как «государственный интерес», которое становится оправданным лишь в случае равнозначности гражданина и власти.

${ }^{20}$ Представляется, что именно поэтому в нашей стране иски против произвола органов государственной власти практически не удовлетворяются, и нашим гражданам приходиться надеяться только на справедливые решения международных судов, над которыми не довлеют рассмотренные нами антиномии.
}

плементирована в российское общественное сознание, зависит, как быстро будут реализованы императивы нашей Конституции в реальной жизни.

\section{Библиография:}

1. Комментарий к Конституции Российской федерации. Под ред. В.Д.Зорькина, Л.В.Лазарева. М.: Эксмо, 2009

2. Кант И. Критика практического разума. // Кант И. Сочинения. В 6-ти тт. Т.4, ч.1. М.: Мысль, 1965

3. Кочетков В.В. Еще раз о сущности социального государства.// Закон и право, 2009, № 7, сc.5-13

4. Кочетков В.В., Кочеткова Л.Н. Социальное государство как идеальный тип.// Труд и социальные отношения, 2010, №6, сс. 106-115

5. Кутафин О.Е. Российский конституционализм. М.: Норма, 2008

6. Политико-правовые ценности: История и современность. Под ред. В.С.Нерсесянца. М.: Эдиториал УРСС, 2000

7. Кочетков В.В. Русские ценности и российская Конституция 1993 года // Право и политика. - 2013. - 13. - C. 1855-1865. DOI: 10.7256/18119018.2013.13.9736.

8. Н.С. Бондарь Конституционное правосудие и развитие конституционной юриспруденции в России: теория и практика. // Журнал зарубежного законодательства и сравнительного правоведения. - 2011. - 4. - C. 6-15.

9. Алейников А.В. Системные конфликты в России: концептуальные основания анализа. Статья 1. // NB: Проблемы общества и политики. - 2013. 7. - C. $94-140$. URL: http://www.e-notabene.ru/pr/ article_2306.html

10. Сулейманов Б.Б. Суд в системе государственной власти (методологические аспекты) // Актуальные проблемы российского права. - 2013. - 3. - С. 239244.

11. В.В. Кочетков. Российская элитология: наука или идеология?. // Политика и Общество. - 2013. № 4. - C. 515-525. DOI: .10.7256/1812-8696.2013.04.18

12. Л.Н. Кочеткова. Итоги, проблемы и перспективы социального государства в России. // Политика и Общество. - 2013. - № 3. - С. 256-262. DOI: $.10 .7256 / 1812-8696.2013 .03 .1$

13. Р.К. Искужин. Методологический кризис российского федерализма. // Политика и Общество. - 2013. - № 1. - C. 17-23. DOI: .10.7256/1812 - 8696.2013.01.2 


\section{Право и политика 6 (174) • 2014}

14. С. Ю. Поярков. Конституционализм в структуре идеологии политического режима.. // Политика и Общество. - 2010. - № 9.

15. А.В. Безруков. Роль Президента России в механизме реализации конституционных принципов федерализма, единства государственной власти и разделения властей. // Политика и Общество. - 2013. - № 3. - С. 263-269. DOI: .10.7256/18128696.2013.03.2

16. С.Ю. Поярков. Система государственной власти: понятие, принципы, функции. // Философия и культура. - 2011. - № 9. - С. 103-115.

17. С. Ю. Поярков. Конституционные гарантии совершенствования механизма обеспечения прав и свобод человека.. // Национальная безопасность / nota bene. -2010 . - № 9 .

18. С.Ю. Поярков. Идеологический процесс российского конституционализма и безопасность государственности. // Национальная безопасность / nota bene. -2010 . - № 1.

19. С.Ю Поярков. Идейно-ценностные основания идеологии Российского конституционализма. // Философия и культура. - 2009. - № 12.

20. Борисенков А.А. О новой парадигме в политической науке // NB: Проблемы общества и политики. -2012. - 2. - C. $22-54$. URL: http://www.e-notabene. $\mathrm{ru} / \mathrm{pr} /$ article_202.html

21. Алейников А.В. Системные конфликты в России: концептуальные основания анализа. Статья 1. // NB: Проблемы общества и политики. - 2013. - 7. - C. 94 - 140. DOI: 10.7256/2306-0158.2013.7.2306. URL: http://www.e-notabene.ru/pr/article_2306.html

22. Чиронова И.И. Когнитивная структура концепта «Власть» в русскоязычном и англоязычном политических дискурсах // Право и политика. - 2013. - 12. - C. 1720 - 1730. DOI: 10.7256/18119018.2013.12.9542.

23. Щупленков О.В., Щупленков Н.О. Конституционные основы информационной свободы в России // NB: Вопросы права и политики. - 2013. - 10. - С. 35 92. DOI: 10.7256/2305-9699.2013.10.9617. URL: http:// www.e-notabene.ru/lr/article_9617.html

\section{References (transliteration):}

1. Kant I. Kritika prakticheskogo razuma. // Kant I. Sochineniya. V 6-ti tt. T.4, ch.1. M.: Mysl', 1965

2. Kochetkov V.V. Eshche raz o sushchnosti sotsial'nogo gosudarstva.// Zakon i pravo, 2009, № 7, ss.5-13
3. Kochetkov V.V., Kochetkova L.N. Sotsial'noe gosudarstvo kak ideal'nyi tip.// Trud i sotsial'nye otnosheniya, 2010, №6, ss. 106-115

4. Kutafin O.E. Rossiiskii konstitutsionalizm. M.: Norma, 2008

5. Kochetkov V.V. Russkie tsennosti i rossiiskaya Konstitutsiya 1993 goda // Pravo i politika. - 2013. - 13. C. 1855-1865. DOI: 10.7256/1811-9018.2013.13.9736.

6. N.S. Bondar' Konstitutsionnoe pravosudie i razvitie konstitutsionnoi yurisprudentsii $\mathrm{v}$ Rossii: teoriya $\mathrm{i}$ praktika. // Zhurnal zarubezhnogo zakonodatel'stva i sravnitel'nogo pravovedeniya. - 2011. - 4. - C. 6-15.

7. Aleinikov A.V. Sistemnye konflikty v Rossii: kontseptual'nye osnovaniya analiza. Stat'ya 1. // NB: Problemy obshchestva i politiki. -2013. - 7. - C. 94-140. URL: http://www.e-notabene.ru/pr/article_2306.html

8. Suleimanov B.B. Sud v sisteme gosudarstvennoi vlasti (metodologicheskie aspekty) // Aktual'nye problemy rossiiskogo prava. - 2013. - 3. - C. 239-244.

9. V.V. Kochetkov. Rossiiskaya elitologiya: nauka ili ideologiya?. // Politika i Obshchestvo. - 2013. - № 4. C. 515-525. DOI: .10.7256/1812-8696.2013.04.18

10. L.N. Kochetkova. Itogi, problemy i perspektivy sotsial'nogo gosudarstva v Rossii. // Politika i Obshchestvo. - 2013. - № 3. - C. 256-262. DOI: $.10 .7256 / 1812-8696.2013 .03 .1$

11. R.K. Iskuzhin. Metodologicheskii krizis rossiiskogo federalizma. // Politika i Obshchestvo. - 2013. - № 1. - C. 17-23. DOI: .10.7256/1812 - 8696.2013.01.2

12. S. Yu. Poyarkov. Konstitutsionalizm v strukture ideologii politicheskogo rezhima.. // Politika i Obshchestvo. - 2010. - № 9.

13. A.V. Bezrukov. Rol' Prezidenta Rossii v mekhanizme realizatsii konstitutsionnykh printsipov federalizma, edinstva gosudarstvennoi vlasti i razdeleniya vlastei. // Politika i Obshchestvo. - 2013. - № 3. - C. 263-269. DOI: .10.7256/1812-8696.2013.03.2

14. S.Yu. Poyarkov. Sistema gosudarstvennoi vlasti: ponyatie, printsipy, funktsii. // Filosofiya i kul'tura. 2011. - № 9. - C. 103-115.

15. S. Yu. Poyarkov. Konstitutsionnye garantii sovershenstvovaniya mekhanizma obespecheniya prav i svobod cheloveka.. // Natsional'naya bezopasnost' / nota bene. -2010. - № 9.

16. S.Yu. Poyarkov. Ideologicheskii protsess rossiiskogo konstitutsionalizma i bezopasnost' gosudarstvennosti.// Natsional'naya bezopasnost' / nota bene. - 2010. - № 1.

17. S.Yu Poyarkov. Ideino-tsennostnye osnovaniya ideologii Rossiiskogo konstitutsionalizma. // Filosofiya i kul’tura. - 2009. - № 12. 
18. Borisenkov A.A. O novoi paradigme v politicheskoi nauke // NB: Problemy obshchestva i politiki. - 2012. - 2. - C. 22 - 54. URL: http://www.e-notabene.ru/pr/ article 202.html

19. Aleinikov A.V. Sistemnye konflikty v Rossii: kontseptual'nye osnovaniya analiza. Stat'ya 1. // NB: Problemy obshchestva i politiki. - 2013. - 7. - C. 94 140. DOI: 10.7256/2306-0158.2013.7.2306. URL: http:// www.e-notabene.ru/pr/article_2306.html
20. Chironova I.I. Kognitivnaya struktura kontsepta «Vlast'» $\mathrm{v}$ russkoyazychnom i angloyazychnom politicheskikh diskursakh // Pravo i politika. - 2013. - 12. - C. 1720 1730. DOI: 10.7256/1811-9018.2013.12.9542.

21. Shchuplenkov O.V., Shchuplenkov N.O. Konstitutsionnye osnovy informatsionnoi svobody v Rossii // NB: Voprosy prava i politiki. - 2013. - 10. - C. $35-92$. DOI: $10.7256 / 2305-9699.2013 .10 .9617$. URL: http:// www.e-notabene.ru/lr/article 9617.html 